DOI: $10.17707 /$ AgricultForest.64.1.20

\author{
Șerban CHIVULESCU, Ștefan LECA, \\ Diana SILAGHI, Valentin CRISTEA ${ }^{1}$
}

\title{
STRUCTURAL BIODIVERSITY AND DEAD WOOD IN VIRGIN FORESTS FROM EASTERN CARPATHIANS
}

\begin{abstract}
SUMMARY
Owing to the high rate of global industrialization, widely distributed forest areas have decreased. Few of these natural forests have succeeded to remain untouched by human activities. The primary ecosystems are characterized by advanced age, high biodiversity and climax condition. These virgin forest, are found in Buzau Mountains, in the Eastern Carpathians of Romania. For understanding and develop the functional principles of virgin forests, field information was collected from three permanent research plots of one hectare area.

Gini index $(\mathrm{G}=0,68-0,84)$ and Camino index $(\mathrm{H}=1,62-1,74)$ were recorded for all permanent study plots. The obtained values reveal high heterogeneity. Total volume of dead wood is between $54,93 \mathrm{~m}^{3} \cdot \mathrm{ha}^{-1}$ (Șapte Izvoare) and 123, $34 \mathrm{~m}^{3} \cdot \mathrm{ha}^{-1}$ (Penteleu - Viforâta 2), most of it came from coniferous species (fir and spruce). There have been analyzed the relationships between dead wood and alive components using different statistical distribution functions (Beta, Gamma, Weibull), and the quantity of dry biomass and $\mathrm{CO}_{2}$ stock from dead wood was estimated.

Keywords: virgin forests, structural biodiversity, Carpathians, dead wood $\mathrm{CO}_{2}$ stock.

\section{INTRODUCTION}

Owning to the high rate of global industrialization widely distributed forest areas has been diminished. Few of these natural forests have succeeded to remain untouched by human activates. Natural ecosystems which have not been influenced by human activities, like virgin stands, have a more complex structure due to their natural dynamics (Hett and Loucks, 1976, Valbuena et al., 2012). The virgin forests present in Romanian Carpathians have a significant importance for the entire Europe, because they keep the natural values which have been lost from other countries' heritage and are very important in protecting, maintaining and monitoring the biodiversity (Ozcelik, 2009).
\end{abstract}

\footnotetext{
${ }^{1}$ Șerban Chivulescu (corresponding author: serban.chivulescu@gmail.com), National Institute for Research and Development in Forestry "Marin Drăcea" and Institute of Biology of Romanian Academy (SCOSAAR), ROMANIA; Ștefan Leca, Diana Silaghi, National Institute for Research and Development in Forestry "Marin Drăcea", ROMANIA; Valentin Cristea, Faculty of Silviculture and Forest Engineering / Transilvania University of Brasov, ROMANIA

Notes: The authors declare that they have no conflicts of interest. Authorship Form signed online.
} 
An important aspect in stand evolution is the structural biodiversity (Roibu et al., 2008), that is why this element is vital in the research and understanding of the virgin forests functionality.

For describing the biodiversity of stands were used Gini and Camino indexes. Gini index was developed for economical purposes (Sen, 1973, Rouvinen and Kuuluvaien, 2005), but it was also used in ecological studies (Weiner, 1985, Knox et al., 1989, Nilsson, 1994, Stocker, 2002), being the most representative index for structural diversity (Roibu et al., 2008) due to its strictness (Cenușă et al., 2002, Lexerod and Eid, 2006, Roibu et al., 2008).

Dead wood has been recognized to have an important ecological function as a resource for the ecosystems, structural components of the forest and in providing resources and habitats for a wide range of organisms (Ferris and Humphrey, 1999, Saniga and Saniga, 2004, Schuck et al., 2005, Humphrey et al., 2005, Merganičová and Merganič, 2010, Tomescu et al., 2011, Seibold et al., 2015). Dead wood also plays an important role in absorbing carbon (Kueppers et al., 2004, Merganičová and Merganič, 2010) and by this in slowing down the process of global warming.

\section{Study area}

\section{MATERIAL AND METHODS}

Research areas are situated in Southern Carpathians, in Romanian Curvature Mountains, more specific in Penteleu Mountains which are a subdivision of Buzău Mountains (Figure1). One plot has been installed in 2014 (Penteleu - Viforata 2) and the other two were installed in 2015 (Penteleu Viforata 1 and Sapte Izvoare). All plots are characterized by high naturalness and they have relevant criteria's to enclose these forests in virgin forest category from the point of view of Romanian Environmental and Climate changes Ministerial Order 3397/2012 regarding the selection and identification of virgin and cvasi-virgin forests.

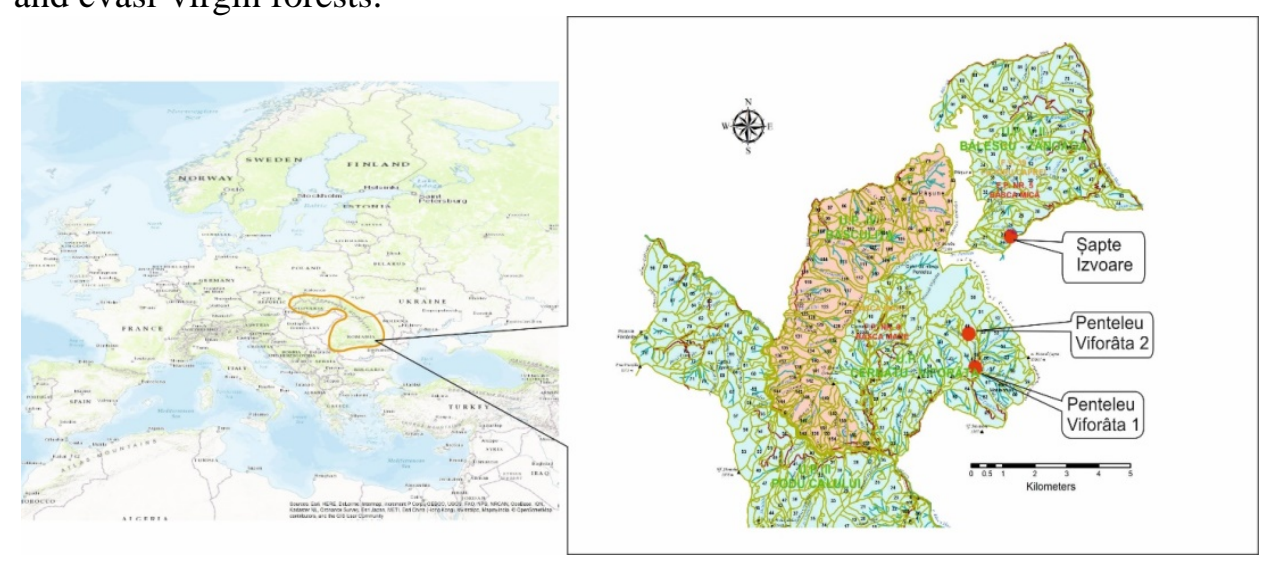

Figure 1. Permanent research plots from Curvature Carpathians (Natural Earth, Esri, ICAS) 


\section{Research method}

Each one of the three researched plots has an area of one hectare - one having a circular shape (Penteleu - Viforâta 2) and the other two having a rectangular shape (Penteleu - Viforâta 1 and Șapte Izvoare). All live trees with diameter at breast height (dbh) higher than $80 \mathrm{~mm}$ were measured and the main dendrometrics characteristics (dbh, height, cenotic class, quality class) were registered. Standing dead wood with dbh higher than $8 \mathrm{~cm}$ and lying dead wood with top diameter higher than $8 \mathrm{~cm}$ were also measured and sampled (Table 1). Standing dead wood volume was calculated using the following regression equation:

$$
\log v=a_{0}+a_{1} \log d+a_{2} \log ^{2} d+a_{3} \operatorname{logh}+a_{4} \log ^{2} h
$$

Where: $\mathrm{h}$ - height of standing dead wood; $\mathrm{d}-\mathrm{dbh}$; v- volume of standing dead wood; $a_{0}, a_{1}, a_{2}, a_{3}, a_{4}$ - regression coefficients (Giurgiu, Decei, Drăghiciu, 2004).

Lying dead wood volume was determined using Huber formula:

$$
v=0.785 \cdot l \cdot \sum d_{i} \text {. }
$$

Table 1. Sampling dead wood

\begin{tabular}{|l|l|c|}
\hline $\begin{array}{l}\text { Dead } \\
\text { wood } \\
\text { category }\end{array}$ & \multicolumn{1}{|c|}{ Description } & Notation \\
\hline Snag 1 & $\begin{array}{l}\text { Standing tree died recently, with the majority of the branches } \\
\text { intact or beginning to break, and intact or almost intact bark and } \\
\text { intact top }\end{array}$ & S 1 \\
\hline Snag 2 & $\begin{array}{l}\text { Standing tree, died a while ago, without top and branches and } \\
\text { also without bark or less bark remained }\end{array}$ & S 2 \\
\hline $\log 1$ & Lying dead wood, still solid, with bark or beginning to lose bark & L 1 \\
\hline Log 2 & Lying dead wood, soft and without bark & L 2 \\
\hline
\end{tabular}

Descriptive statistics was made with help of PASTECS (Grosjean \& Ibanez, 2014) package from RStudio program. Dry biomass and $\mathrm{CO}_{2}$ was sampled for each category of dead wood. For standing dead wood, volume was transformed in biomass using the relation:

$$
\mathrm{DB}=\mathrm{V} \bullet \mathrm{WD} \text { (Goslee et al., 2014) }
$$

Where:DB is dry biomass; WD is wood density

WD was taken from wood density Romanian tables (Giurgiu, Decei, Drăghiciu, 2004) and was applied a reduction density factor according to the level of deterioration (UNFCC, 2013). Thereafter DB was transformed into $\mathrm{CO}_{2}$ stock $\left(\mathrm{C}_{\mathrm{SDW}}\right)$ using the relation:

$$
\mathrm{C}_{\mathrm{SDW}}=\mathrm{DB} \cdot \mathrm{CF} \text { (Goslee et al., 2014) }
$$

Where: CF - carbon fraction usually used in the literature (IPCC 2006) GL,V4, CH4, (Table 4.3) with the value of 0,47 t/ha. 
The relation used to determine dry biomass from lying dead wood was:

$\mathrm{BM}=\mathrm{V} \cdot \mathrm{Dc}$ (Goslee et al., 2014)

Where:BM represents the dry biomass; $\mathrm{V}$ is volume of lying dead wood; Dc is medium density class (Walker et al., 2012).

Lying dead wood carbon stock $\left(\mathrm{C}_{\mathrm{LDW}}\right)$ was determined using a relation which is composed of dry biomass (BM) and carbon fraction (CF):

$$
\mathrm{C}_{\mathrm{LDW}}=\mathrm{BM} \cdot \mathrm{CF} \text { (Goslee et al., 2014) }
$$

Where: CF value used was 0,47 t/ha (IPCC 2006 GL, V4, CH4, Table 4.3).

Structural biodiversity analyzes were made using Gini (Gini, 1912) and Camino (Camino, 1976) indexes, and the graphic representation was attained using Lorenz curve (Lorenz, 1905). Gini biodiversity index, unlike other indexes, has a high quality in describing the structural diversity, (Cenusa, 2002, Lexerod and Eid, 2006, Roibu, 2008, Duduman, 2011, Klopcic and Boncina, 2011). Lorenz curve is a good indicator, used for describing the equitability of stands (Studeny et all, 2011, Valbuena, 2012).

To determine heterogeneity were also used other structural indexes like Shannon (Shannon, 1948) and Evenness (Pielou, 1969) using package BiodiversityR (Kindt and Coe, 2005) from RStudio program. The experimental dead wood (DW) volume distribution was computed using the program Mathwave EasyFit. In order to compare the experimental values with the theoretical ones were used Exponential, Gamma, Lognormal and Weibull functions and the goodness-of fit was tested using hi square criterion $\left(\chi^{2}\right)$, Kolmogorov Smirnov (KS) and Anderson-Darling (AD) tests.

\section{RESULTS}

\section{Relationship between dead wood and alive trees}

The presence of dead wood in virgin forest is very important and to highlight its role it was correlated with alive trees (Table 2).

Table 2. Relation between dead wood and alive trees

\begin{tabular}{|c|c|c|c|c|c|c|c|c|c|}
\hline \multirow{3}{*}{$\begin{array}{l}\text { Research } \\
\text { Plot }\end{array}$} & \multicolumn{6}{|c|}{ Volume, $\mathrm{m}^{3}$} & \multirow{2}{*}{\multicolumn{3}{|c|}{$\% \mathrm{DW}$ from AT }} \\
\hline & \multicolumn{3}{|c|}{ Dead wood (DW) } & \multicolumn{3}{|c|}{ Alive trees (AT) } & & & \\
\hline & Coniferous & Beech & Total & Coniferous & Beech & Total & Coniferous & Beech & Total \\
\hline $\begin{array}{c}\text { Şapte } \\
\text { Izvoare }\end{array}$ & 50,060 & 4,876 & 54,936 & 743,112 & 162,342 & 905,454 & 7 & 3 & 6 \\
\hline $\begin{array}{l}\text { Penteleu - } \\
\text { Viforâta } 1\end{array}$ & 65,001 & 7,350 & 72,351 & 835,212 & 298,311 & 1133,523 & 8 & 2 & 6 \\
\hline $\begin{array}{l}\text { Penteleu - } \\
\text { Viforâta } 2\end{array}$ & 96,891 & 26,458 & 123,349 & 446,614 & 357,218 & 803,831 & 22 & 7 & 15 \\
\hline Total & 211,952 & 38,684 & 250,636 & 2024,938 & 817,871 & 2842,808 & 37 & 12 & 27 \\
\hline Mean & 70,651 & 12,895 & 83,546 & 674,979 & 272,624 & 947,603 & 10 & 5 & 9 \\
\hline
\end{tabular}


In all research plots, most of dead wood comes from coniferous species with a volume between $50.060 \mathrm{~m}^{3} \cdot \mathrm{ha}^{-1}$ (Șapte Izvoare) and $96.891 \mathrm{~m}^{3} \cdot \mathrm{ha}^{-1}$ (Penteleu - Viforâta 2). Beech dead wood volume is between $4,876 \mathrm{~m}^{3} \cdot \mathrm{ha}^{-1}$ (Șapte Izvoare) and $26,458 \mathrm{~m}^{3} \cdot \mathrm{ha}^{-1}$ (Penteleu - Viforâta 2), less significant than dead wood derived from coniferous. Total volume of dead wood it varies between 54,936 $\mathrm{m}^{3} \cdot \mathrm{ha}^{-1}$ (Șapte Izvoare) and 123,349 $\mathrm{m}^{3} \cdot \mathrm{ha}^{-1}$ (Penteleu Viforâta 2), with an average of 83,546 $\mathrm{m}^{3} \cdot \mathrm{ha}^{-1}$. The percentage of DW from AT for coniferous is between $7 \%$ and $22 \%$, with an average of $10 \%$, while for beech is between $2 \%$ and $7 \%$ with an average of $5 \%$. The total percentage between dead wood and alive trees varies between $6 \%$ and $15 \%$, having an average of $9 \%$.

\section{Descriptive statistics of volume for dead wood}

Number of samples of dead wood is between 63 (Penteleu - Viforâta 2) and 237 (Penteleu - Viforâta 1)(Table 3). Analyzing the results, it may be observed that lowest volume value of dead wood is 0,003 cubic meters (Penteleu - Viforâta 1) while the highest volume value is around 17 cubic meters (Penteleu - Viforâta 2 -volume which corresponds to a piece of lying dead wood having $104 \mathrm{~cm}$ breast diameter and $34 \mathrm{~m}$ length ). The Șapte Izvoare research plot has the lowest volume value of dead wood $\left(54,936 \mathrm{~m}^{3}\right)$ while Penteleu - Viforâta 2 registers the highest volume value of dead wood $\left(123,349 \mathrm{~m}^{2}\right)$. The coefficient of variation is between 1,588 (Șapte Izvoare) and 3,076 (Penteleu - Viforâta 1), and standard deviation is between 0,364 (Șapte Izvoare) and 3,240 (Penteleu Viforâta 2).

Table 3. Descriptive statistics of volume of dead wood

\begin{tabular}{|c|c|c|c|c|c|c|c|c|c|c|}
\hline $\begin{array}{c}\text { Research } \\
\text { Plot }\end{array}$ & $\begin{array}{c}\text { number } \\
\text { of } \\
\text { values }\end{array}$ & Min & Max & Range & sum & median & mean & Var & std.dev & coef.var \\
\hline Şapte Izvoare & 218 & 0.005 & 3.059 & 3.054 & 54.936 & 0.091 & 0.229 & 0.132 & 0.364 & 1.588 \\
\hline $\begin{array}{c}\text { Penteleu - } \\
\text { Viforâta 1 }\end{array}$ & 237 & 0.003 & 8.210 & 8.208 & 72.351 & 0.049 & 0.305 & 0.882 & 0.939 & 3.076 \\
\hline $\begin{array}{c}\text { Penteleu - } \\
\text { Viforâta 2 }\end{array}$ & 63 & 0.052 & 17.390 & 17.338 & 123.349 & 0.643 & 1.958 & 10.498 & 3.240 & 1.655 \\
\hline
\end{tabular}

\section{Dead wood volume in relation with decay class}

Depending on the category of decay (Table 4), in Șapte Izvoare and Penteleu - Viforâta 2 research plots it may be observed that most of dead wood falls into the category Snag 2 (Standing tree, died a while ago, without top and branches and also without bark or less bark remained) (Table 2), whereas in Penteleu Viforâta 1 most of dead wood volume falls in Log 1 (Lying dead wood, still solid, with bark or beginning to lose bark).

\section{Fitting of experimental DW volume distribution}

To compare experimental and theoretical values Exponential, Gamma, Lognormal and Weibull theoretical functions were used (Figure 2). 
Table 4. Dead wood volume according to decay class

\begin{tabular}{|c|c|c|c|c|}
\hline \multirow{2}{*}{$\begin{array}{c}\text { Dead wood } \\
\text { category }\end{array}$} & \multicolumn{3}{|c|}{ Volume, m } & \multirow{2}{*}{ Mean } \\
\cline { 2 - 4 } Snag 1 & Șapte Izvoare & Penteleu - Viforâta 1 & Penteleu - Viforâta 2 & \\
\hline Snag 2 & 11,181 & 12,701 & 13,658 & 12,513 \\
\hline $\log 1$ & 25,582 & 29,060 & 91,513 & 48,718 \\
\hline $\log 2$ & 17,532 & 30,590 & - & 16,041 \\
\hline Total & 0,641 & - & 18,178 & 6,273 \\
\hline
\end{tabular}

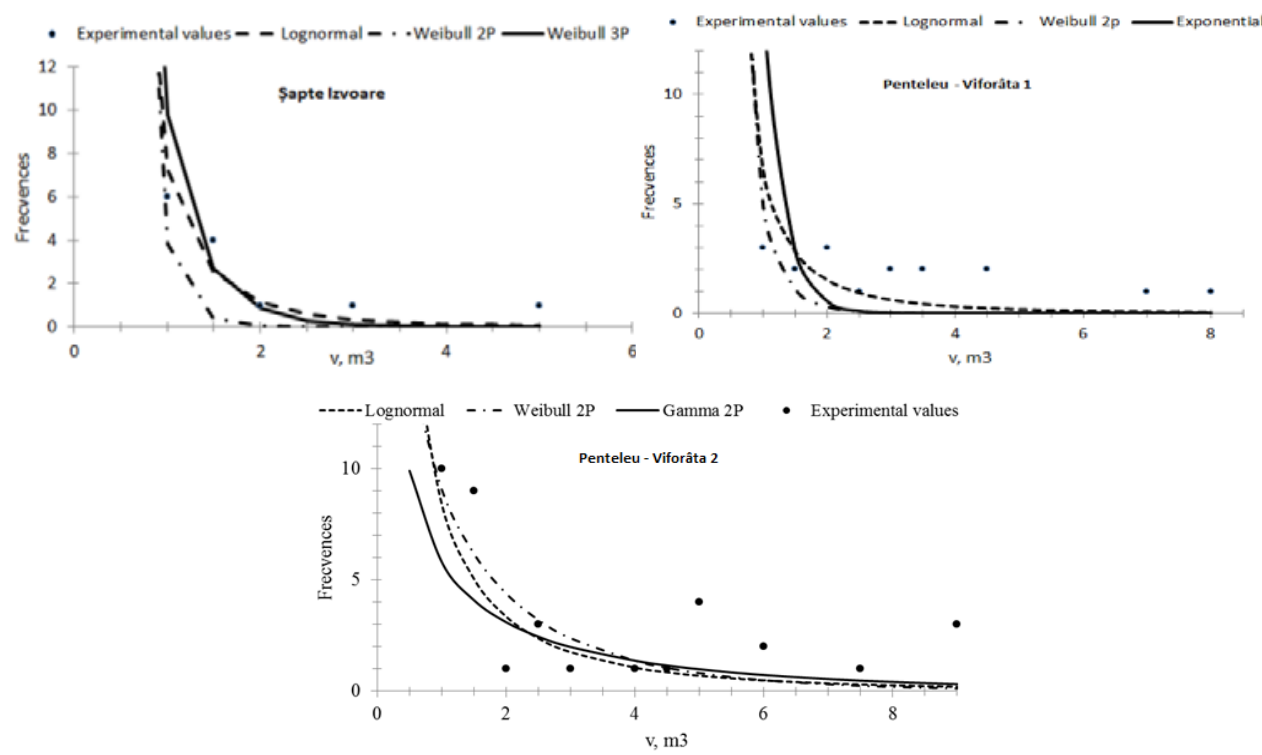

Figure 2. Dead wood volume distribution adjusted with theoretical functions

In order to determine which theoretical frequencies law is most suitable for describing this type of distribution the goodness of fit was tested, using $\chi^{2}$ criterion, K-S and A-D tests (Table 5).

Table 5. Experimental values of specific goodness-of-fit tests

\begin{tabular}{|c|c|c|c|c|c|c|c|}
\hline \multirow{2}{*}{$\begin{array}{c}\text { Research } \\
\text { plot }\end{array}$} & \multirow{2}{*}{\begin{tabular}{c} 
Distribution \\
\cline { 3 - 8 }
\end{tabular}} & \multicolumn{2}{|c|}{$\begin{array}{c}\text { Kolmogorov Smirnov } \\
\text { Test KS) }\end{array}$} & $\begin{array}{c}\text { Anderson Darling Test } \\
\text { (AD) }\end{array}$ & \multicolumn{2}{|c|}{$\chi^{2}$ Criterion $\left(\chi^{2}\right)$} \\
\hline \multirow{2}{*}{$\begin{array}{c}\text { Spapte } \\
\text { Izvoare }\end{array}$} & Lognormal & 0,069 & 0,092 & 1,086 & 2,501 & 5,474 & 14,067 \\
\cline { 2 - 8 } & Weibull 2P & 0,129 & 0,092 & 5,329 & 2,501 & 22,546 & 14,067 \\
\cline { 2 - 8 } & Weibull 3P & 0,099 & 0,092 & 3,194 & 2,501 & 39,084 & 14,067 \\
\hline \multirow{2}{*}{$\begin{array}{c}\text { Penteleu } \\
\text { Viforâta1 }\end{array}$} & Lognormal & 0,061 & 0,088 & 1,074 & 2,501 & 8,819 & 14,067 \\
\cline { 2 - 8 } & Weibull 2P & 0,116 & 0,088 & 7,498 & 2,501 & 15,561 & 14,067 \\
\cline { 2 - 8 } & Exponential & 0,409 & 0,088 & 104,92 & 2,501 & 283,07 & 14,067 \\
\hline \multirow{2}{*}{$\begin{array}{c}\text { Penteleu- } \\
\text { Viforâta2 } 2\end{array}$} & Lognormal & 0,07 & 0,168 & 0,383 & 2,501 & 0,837 & 5,991 \\
\cline { 2 - 8 } & Weibull 2P & 0,101 & 0,168 & 1,471 & 2,501 & 5,473 & 5,991 \\
\cline { 2 - 8 } & Gamma 2P & 0,212 & 0,168 & 3,011 & 2,501 & 0,018 & 5,991 \\
\hline
\end{tabular}




\section{Estimating dry biomass and $\mathrm{CO}_{2}$ sequestration from dead wood}

For all research plots dry biomass and $\mathrm{CO}_{2}$ stock were obtained using allomeric equations (Table 6) related to dead wood volume.

Table 6. Values of dry biomass and $\mathrm{CO}_{2}$ estimated

\begin{tabular}{|l|c|c|c|}
\hline \multicolumn{1}{|c|}{ Research Plot } & $\begin{array}{c}\text { DW volume } \\
\mathrm{m}^{3} \cdot \mathrm{ha}^{-1}\end{array}$ & $\begin{array}{c}\text { Dry biomass } \\
\text { tones } \bullet \mathrm{ha}^{-1}\end{array}$ & $\begin{array}{c}\mathrm{CO}_{2} \text { stock } \\
\text { tones } \bullet \mathrm{ha}^{-1}\end{array}$ \\
\hline Șapte Izvoare & 54,93 & 19,65 & 9,23 \\
\hline Penteleu - Viforâta 1 & 72,35 & 24,12 & 11,34 \\
\hline Penteleu - Viforâta 2 & 123,34 & 29,91 & 14,06 \\
\hline Average & 83,54 & 24,56 & 11,54 \\
\hline
\end{tabular}

Quantity of dry biomass is between 19.65 tones $\bullet$ ha $^{-1}$ and 29.91 tones $\bullet$ ha $^{-1}$ with an average of 24.56 tones $\cdot$ ha $^{-1}$. The dead wood from research plots sequesters approximatively a quantity on $\mathrm{CO}_{2}$ ranging from 9.23 tones $\bullet \mathrm{ha}^{-1}$ to 14.09 tones $\cdot$ ha $^{-1}$, with an average of 11.54 tones $\bullet$ ha $^{-1}$.

\section{Analyzes of structural biodiversity}

Structural biodiversity it is an important component of virgin forests and Lorenz curve succeeds to represent this in a graphical way (Figure 3).
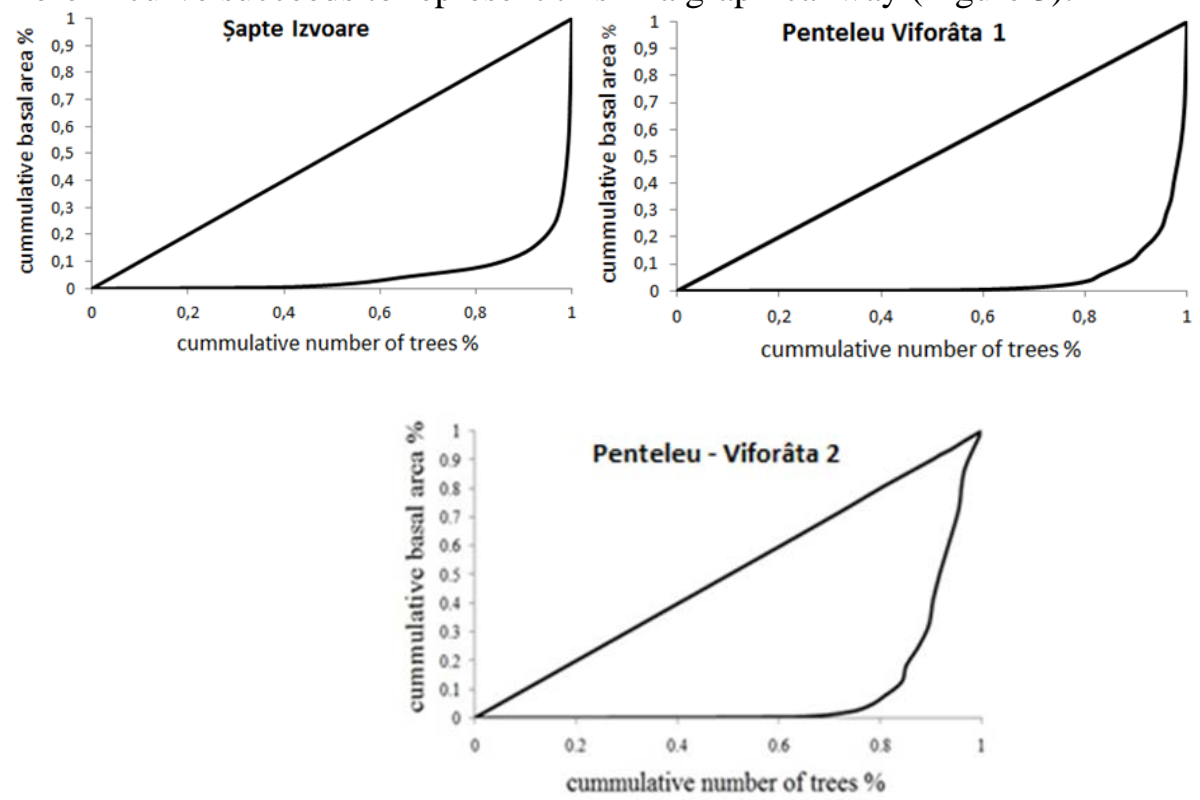

Figure 3. Lorenz curve for research plots Șapte Izvoare, Penteleu Viforâta 1, Penteleu - Viforâta 2

Collected data from research plots were verified using special tests to indicate the level of heterogeneity. The values for $G$ index from research plots are between 0.69 and 0.84 and the values for $\mathrm{H}$ index are between 1.62 and 1.74 (Table 7). 
Table 7. Values of $\mathrm{G}$ and $\mathrm{H}$ indexes for testing structural homogeneity

\begin{tabular}{|l|c|c|}
\hline \multicolumn{1}{|c|}{ Research Plot } & Gini index $(\mathrm{G})$ & Camino index $(\mathrm{H})$ \\
\hline Şapte Izvoare & 0,69 & 1,71 \\
\hline Penteleu - Viforâta 1 & 0,71 & 1,62 \\
\hline Penteleu - Viforâta 2 & 0,84 & 1,74 \\
\hline
\end{tabular}

To describe structural biodiversity using diameter data, were calculated indexes like Evenness and Shannon, which are the most popular among all alternative indexes (Valbuena et al., 2012). In our research plots, Shannon index $(\mathrm{SH})$ is between 2.69 and 2.80, and values of Evenness index $(\mathrm{E})$ is between 0.78 and 0.81 (Table 8).

Table 8. Values of E and SH indexes for testing structural homogeneity

\begin{tabular}{|l|c|c|}
\hline \multicolumn{1}{|c|}{ Research Plot } & Shannon index (SH) & Evenness index (E) \\
\hline Şapte Izvoare & 2,77 & 0,81 \\
\hline Penteleu - Viforâta 1 & 2,80 & 0,82 \\
\hline Penteleu - Viforâta 2 & 2,69 & 0,78 \\
\hline
\end{tabular}

\section{DISCUSSION}

The large number and quantity of dead wood samples highlight a high heterogeneity of the researched stands. The amount of dead wood volume mentioned in literature falls into a range between $50 \mathrm{~m}^{3} \mathrm{ha}^{-1}$ and $200 \mathrm{~m}^{3} \mathrm{ha}^{-1}$ (Jedicke, Scherzinger, 1996). The high heterogeneity of dead wood is indicated by low values of standard deviation and the variation coefficient. Regarding the dead wood distribution according to the decay class, it may be observed that the forest stands weren't influenced by anthropic activities, dead wood was never harvested. The presence of considerably quantities of dead wood in different decay stages stabilizes the ecosystems and are providing food and habitats for many species as well as maintaining the health status (Tomescu et al., 2011).

Distribution of dead wood volume has a descending trend, with high values at small categories and a shape of reverse "J" (Westphal et al, 2006) characteristic for virgin stands. Goodness of fit for Șapte Izvoare and Penteleu Viforâta 1 plot shows that all the conformity tests, indicate that the most suitable functions is Lognormal. Testing experimental values of Penteleu-Viforata 2 with theoretical function Lognormal, Gamma and Weibull, the $\chi^{2}$ criterion shows that all functions studied are suitable for describing the stand.

Also, Kolmogorov-Smirnov test show no differences between experimental and theoretical distribution for Lognormal and Weibull functions.

The relationships between dead and alive trees are influenced by the development stage of the stand, and the natural factors like wind, snow and insect's attacks. For all researched plots, most dead wood comes from coniferous, fact explained by the physiological age differences of beech and coniferous. The quantity of DW is important because it maintains the entomologic balance 
between predators and parasites (Tomescu, 2011, 2013) and in this way, is demonstrated the superiority of virgin forests.

The carbon stock from dead wood, determined in our research, is higher than the one reported by Karankina et. al (2002), from Russian boreal forests (0.1-0.7 tones $\left.\bullet \mathrm{ha}^{-1}\right)$. Comparative to other research of virgin forests, the quantity of stocked carbon in dead wood fall in the lower limit of the interval, respective from 1.6 to 64.4 tones $\cdot$ ha $^{-1}$ (Merganicova and Merganic, 2010), highlighting the high capacity of virgin forests in absorbing carbon.

The heterogeneity of researched plots is high, fact demonstrated by the large area between Lorenz curve and Equality line, specific to uneven aged stands and implicit to virgin stands. Also, Equality line represents a reference point for studying forest dynamics and stand development (Valbuena et al, 2012).

In our research, values of $\mathrm{G}$ index are higher than the lower limit (>0.51) found in other research (Duduman, 2011, Valbuena et al., 2012) and close to maximum in others (Chivulescu et al., 2014). Regarding the coefficient of heterogeneity $\mathrm{H}$ for uneven aged stands, this was established to be between 1.3 and 2.8 (Ozcelik, 2009). The obtained values of $\mathrm{H}$ index in our research plots $(1,62-1,74)$, demonstrate that the diversity is high and the stands have the characteristics of virgin uneven aged forests.

Shannon index has been used widely in the past for describing heterogeneity in ecological studies (LeMay and Staudhammer, 2005, Barbeito and Cañellas, 2009, Ercanli and Kahriman, 2015). Values between 0.0 and 2.30 for Shannon index are specific to uneven aged forests (Ercanli and Kahrimon 2015, Roibu - 2010). In all researched plots the structural heterogeneity is high, fact demonstrated by the values of Shannon index (the obtained values are between 2.07 and 2.91 .

\section{CONCLUSIONS}

This research highlights the capacity of virgin forests to maintain the stability of stands by its biodiversity. Biodiversity also maintained by the quantity of dead wood which provides food and habitats for many species. The presence of dead wood, in different decay stages, indicates that the ecosystems haven't been influenced by anthropic activities.

The dead wood distribution has a descending trend and the most suitable function to describe this type of ecosystems, in most cases, was Lognormal theoretical function. Also, was demonstrated that the stage development of stand and natural influences like snow, wind and insect attacks, influence the relationship between dead and alive trees.

The quantity of carbon stocked in dead wood was higher than the one registered in other research.

The high heterogeneity of the researched stands is demonstrated by the large area between Lorenz curve and Equality line, which is specific to uneven aged stands, but also by the values obtained using Gini, Camino, Evenness and Shannon indexes. 
The most important fact demonstrated in this research is that the virgin forests are superior to managed forests and preserving this type of ecosystems is very important to humankind.

\section{REFERENCES}

Bachofen, H., \& Zingg, A. (2001). Effectiveness of structure improvement thinning on stand structurein subalpine Norway spruce (Picea abies (L.) Karst.) stands. Forest Ecology and Management, 145(1), 137-149.

Barbeito, I., Cañellas, I., \& Montes, F. (2009). Evaluating the behaviour of vertical structure indices in Scots pine forests. Annals of forest science, 66(7), 1-10.

Cenuşă, R., Popa, C., \& Teodosiu, M. (2002). Cercetări privind relaţia structură-funcţie şi evoluţia ecosistemelor forestiere naturale din nordul ţării. Anale ICAS, 45, 9-19.

Chivulescu, S., Badea, O., Tomescu, R., Silaghi, D., Leca,S., \& Turcu, D. O. (2014). Structural features of virgin beech forests in Semenic mountains. The dynamic structure of virgin beech forest P20 Semenic between 2005-2013. Proceedings of Romanian Academy - Series B: Chemistry, Life Science and Geoscience, 16 (2), $115-124$.

De-Camino, R. (1976). Determinación de la homogeneidad de rodales. Bosque, 1(2), 110-115.

Duduman, G. (2011). A forest management planning tool to create highly diverse uneven-aged stands.Forestry, cpr014.

Ercanli, İ., \& Kahriman, A. (2015). The evaluation of different forest structural indices to predict the stand aboveground biomass of even-aged Scotch pine (Pinus sylvestris

L.) forests in Kunduz, Northern Turkey. Environmental monitoring and assessment, 187(3), 1-14.

ESRI (2016): World Topographic Map - Sources: Esri, HERE, DeLorme, Intermap,increment P Corp., GEBCO, USGS, FAO, NPS, NRCAN, GeoBase, IGN, Kadaster NL, Ordnance Survey, Esri Japan, METI, Esri China (Hong Kong), swisstopo, MapmyIndia, (C) OpenStreetMap contributors, and the GIS User Community.

Ferris, R., \& Humphrey, J. W. (1999). A review of potential biodiversity indicators for application in British forests. Forestry, 72(4), 313-328.

Gini, C. (1912). Variabilità e mutabilità. Reprinted in Memorie di metodologica statistica (Ed. Pizetti E, Salvemini, T). Rome: Libreria Eredi Virgilio Veschi, 1.

Giurgiu V., Decei I., Drăghiciu D. (2004): Metode şi tabele dendrometrice. București, Editura Ceres: 575.

Goslee K., Walker S.M., Grais. A., Murray L., Carasim F., Brown S. (2014): Technical Guidance Series: Module C-CS: Calculation for estimating Carbon Stocks. LEAF REDD: 44.

Grosjean, P., \& Ibanez, F.(2014): Package for Analysis of Space-Time Ecological Series. PASTECS version 1.3-18 for R v. 3.1. 1

Hett, J. M., \& Loucks, O. L. (1976). Age structure models of balsam fir and eastern hemlock. The Journal of Ecology, 1029-1044.

Humphrey, J. W., Sippola, A. L., Lempérière, G., Dodelin, B., Alexander, K. N. A., \& Butler, J. E. (2005). Deadwood as an indicator of biodiversity in European forests: from theory to operational guidance. EFI Proc, 51, 193-206.

ICAS, (2011): Amenajamentul UP V Cernatu - Viforâta, Ocolul Silvic Penteleu.

IPCC (2006): Guidelines for National Greenhouse Gas Inventories, Volume 4, Chapter 4, Forest Land: 83. 
Jedicke E., Scherzinger W. (1996): Naturschutz im Wald. Qualitaetsziele einer dynamischen

Kindt, R. \& Coe, R. (2005) Tree diversity analysis: A manual and software for common statistical methods for ecological and biodiversity studies.

Knox, R. G., Peet, R. K., \& Christensen, N. L. (1989). Population dynamics in loblolly pine stands: changes in skewness and size inequality. Ecology, 70(4), 1153-1167.

Krankina, O. N., Harmon, M. E., Kukuev, Y. A., Treyfeld, R. F., Kashpor, N. N., Kresnov, V. G., ... \& Povarov, E. D. (2002). Coarse woody debris in forest regions of Russia. Canadian Journal of Forest Research, 32(5), 768-778.

Kueppers, L. M., Southon, J., Baer, P., \& Harte, J. (2004). Dead wood biomass and turnover time, measured by radiocarbon, along a subalpine elevation gradient. Oecologia, 141(4), 641-651.

LeMay, V., \& Staudhammer, C. (2005). Indices of stand structural diversity: adding spatial diversity to a stand structural index. Extended abstract. In Proceedings of the IUFRO Sustainable forestry in theory and practice: recent advances in inventory and monitoring conference, Edinburgh, Scotland.

Lexerød, N. L., \& Eid, T. (2006). An evaluation of different diameter diversity indices based on criteria related to forest management planning. Forest Ecology and Management, 222(1), 17-28.

Lorenz, M. O. (1905). Methods of measuring the concentration of wealth. Publications of the American statistical association, 9(70), 209-219.

Merganičová, K., \& Merganič, J. (2010). Coarse woody debris carbon stocks in natural spruce forests of Babia hora. Journal of Forest Science, 56(11), 397-405.

Natural Earth, 2015, Area and point labels of major physical features, Physical vectors, www.naturalearthdata.com

Nilsson, U. (1994). Development of growth and stand structure in Picea abies stands planted at different initial densities. Scandinavian Journal of Forest Research, 9(14), 135-142.

Ozcelik, R. (2009). Tree species diversity of natural mixed stands in eastern Black sea and western Mediterranean region of Turkey.

Pielou, E. C. (1969). An introduction to mathematical ecology. An introduction to mathematical ecology.

Roibu, C. C. (2010). Biometrics and dendrochronological researches in beech forests from Suceava Plateau at Eastern limit of the European areal (Doctoral dissertation, PhD thesis," Ştefan cel Mare" University, Suceava 274 p.[In Romanian]).

Roibu, C., Tomescu, C., Savin, A., \& Miron-Onciul, M. (2008). Analysis of biodiversity regarding structural and phytocoenological aspect in „Humosu Old Growth Beech Forest”Reservation. Romanian Academy Journal, 2, 25-31.

Rouvinen, S., \& Kuuluvainen, T. (2005). Tree diameter distributions in natural and managed old Pinus sylvestris-dominated forests. Forest Ecology and Management, 208(1), 45-61.

Saniga, M., \& Saniga, M. (2004). Influence of forest stand structure on the occurrence of bird community in Skalná Alpa National Nature Reserve in the Vel'ká Fatra Mts.(West Carpathians). Journal of Forest Science, 50, 219-234.

Schuck, A., Meyer, P., Menke, N., Lier, M., \& Lindner, M. (2005). Forest biodiversity indicator: dead wood-a proposed approach towards operationalising the MCPFE indicator. Monitoring and indicators of forest biodiversity in Europe-from ideas to operationality, 51, 49-77. 
Seibold, S., Bässler, C., Brandl, R., Gossner, M. M., Thorn, S., Ulyshen, M. D., \& Müller, J. (2015). Experimental studies of dead-wood biodiversity-a review identifying global gaps in knowledge. Biological Conservation, 191, 139-149.

Sen, A. (1973). On economic inequality. Oxford University Press.

Shannon, C., 1948. A Mathematical Theory of Communication. Bell System Technical Journal 27, 623-656.

Stöcker, G. (2002). Analysis and comparison of stand structures in natural spruce forests with Lorenz functions and Gini Coefficients. Aust. J. For. Sci, 119, 12-39.

Studeny, A. C., Buckland, S. T., Illian, J. B., Johnston, A., \& Magurran, A. E. (2011). Goodness-of-fit measures of evenness: a new tool for exploring changes in community structure. Ecosphere, 2(2), 1-19.

Tomescu R., Târziu D.R., Turcu D-O (2013): Contribuții la cunoașterea dinamicii structurii făgetelor virgine din Rezervația Naturală Izvoarele Nerei-Semenic. In: Giurgiu V. (ed.): Păduri virgine și cvasivirgine ale Romaniei, București, Editura Academiei Române: 209-257

Tomescu, R., Târziu, D. R., \& Turcu, D. O. (2011). The importance of dead wood in the forest.ProEnvironment/ProMediu, 4(7).

UNFCC (2013): Estimation of carbon stocks and change in carbon stocks in dead wood and litter in A/R CDM project activities: 23.

Valbuena, R., Packalén, P., Martı, S., \& Maltamo, M. (2012). Diversity and equitability ordering profiles applied to study forest structure. Forest Ecology and Management, 276, 185-195.

Walker S.M., Pearson T., Casarim F.M., Harris H., Petrova S., Grais A., Swails E., Netzer M., Goslee K.M., Brown S. (2012): Standard Operating Procedures for Terrestrial Carbon Measurement, Version 2012. Winrock International.

Weiner, J. (1985). Size hierarchies in experimental populations of annual plants. Ecology, 66(3), 743-752.

Westphal, C., Tremer, N., von Oheimb, G., Hansen, J., von Gadow, K., \& Härdtle, W. (2006). Is the reverse J-shaped diameter distribution universally applicable in European virgin beech forests. Forest Ecology and Management, 223(1), 75-83. 